\title{
Dynamics of Crude Oil Price Change and Global Food Commodity Prices
}

\author{
Ibrahim Onour \\ School of Management Studies, University of Khartoum, Khartoum, Sudan \\ Email: onour@uofk.edu; ibonour@hotmail.com
}

Doi: https://doi.org/10.38157/finance-economics-review.v3i1.248

Citation: Onour, I. (2021). Dynamics of Crude Oil Price Change and Global Food Commodity Prices, Finance \& Economics Review, 3(1), 38-50. Doi: https://doi.org/10.38157/finance-economics-review.v3i1.248.

\section{Research Article}

\begin{abstract}
Purpose: This study investigates the effect of crude oil price fluctuations (price change as well as volatility) on wheat, sugar, corn, and fertilizers price changes.

Methods: The study employs Markov switching dynamic regression, Dynamic Conditional Correlation (DCC), and Generalized Autoregressive Conditional Hetrosekadicity (GARCH) on monthly data covering the period from January 1988 to April 2018.

Results: The findings of the research support evidence of two states. State 1, pertains to the low volatility of crude oil price, and state 2 belong to the case of the high volatility of crude oil prices. Our results indicated that at state 1, an increase in crude oil prices leads to a decline in food commodity prices, while in state 2, an increase in crude oil price levels causes an increase in food commodity prices. Results of Dynamic Conditional Correlation (DCC) GARCH estimates indicate the coefficients of oil price levels are significant and positively associated with the conditional volatility of the four commodity prices.

Implications: The findings of the research imply that volatility in global food commodity prices is not due to oil price volatility but due to the oil price levels attained at extreme points.

Originality: The paper investigates the impact of different volatility levels of crude oil prices on global food commodity prices.
\end{abstract}

Keywords: Crude oil, food commodities, volatility, GARCH

\section{Introduction}

The rise in the global food prices that began in 2006 set off a surge of food prices inflation around the world, causing food insecurity that triggered violent protests in some countries across the world. Africa was perhaps most affected, despite the problem was global (FAO, 2011). Studies on the impact of high food prices on the poor across some developing countries led to calls for international policy actions that absorb the negative effect on poverty and malnutrition increase. Some authors (Onour and Sergi., 2011; Onour (2010); Jones and Elasri, 2010) attribute the main cause of global food commodity prices rise to crude oil price rises, via multiple transmission venues. As a result, It is strongly believed that the effects of higher 
volatility of oil prices can aggravate volatile and unstable food commodity prices. The transmission effect of crude oil prices on global food prices can pass through multiple routes. Oil price rise can transmit to food markets directly, via shipment and transportation costs rise, or indirectly in the form of increased demand for cereals (corn and sugar cane) for biofuel production purposes, and also by raising the cost of fertilizers (figure 1).

Another factor attributed to global food commodity prices rise in the past decade is the depreciation of the US dollar, in which international prices of crude oil prices tend to be denominated (Hudson 2009). The relationship between currency prices and commodity prices is a bit complex in particular agricultural commodity price changes. The extent to which global commodity prices change translated to domestic consumer and producer price changes in different countries depends on the US dollar exchange rate in these countries as well as a variety of other factors, such as import tariffs, and market structures, that determine the pricing mechanism. This is to say, as commodity prices are commonly denominated in US dollars, depreciation in the value of the US dollar reduces the cost of commodities for countries whose currencies appreciate against the US dollar, creating a shield against a food price increase in local markets. However, for countries whose local currencies are weaker than the US dollar, depreciation in the US dollar increases the cost of purchasing imported commodities. Another explanation of global food commodity price increases in the past is due to increased demand for certain agricultural commodities used for feed stocks for biofuel production, particularly maize or sugar cane for ethanol.

Crude oil price hikes and environmental concerns raised interest in alternative energy sources and policy measures in the US, and in European countries encouraging more production of biofuel. Another explanation of food commodity price increase is rapid economic growth in certain emerging economies, notably China and India, for livestock products, and demand rise for food which generated increased cereal and oilseed demand for feed. Another factor that has been cited in the literature includes the effect of speculative funds that have been invested in agricultural commodity futures markets as the global financial crisis weakened demand for bonds and stock market shares. These explanations suggest a structural change in global food commodity prices due to fundamental new drivers that may persist for a quite long time in the future. Also conventional explanations of supply-side factors such as droughts and other environmental calamities in North America, Australia, and Russia, in addition to other cereal producers also relevant to the discussion of global food commodity price changes. Whatever, the causes of global food price changes, the importance of this research stems from the view that unpredictability of future food commodity prices can cause problems to poor households as they become more constrained to adjust their food spending budget to price rises and producers fail to respond in time to the rising prices due to the seasonal time-cycle of agricultural production. Furthermore, the disruptive nature of the supply of food production and globally increasing demand for food commodities make the global food market thin. 


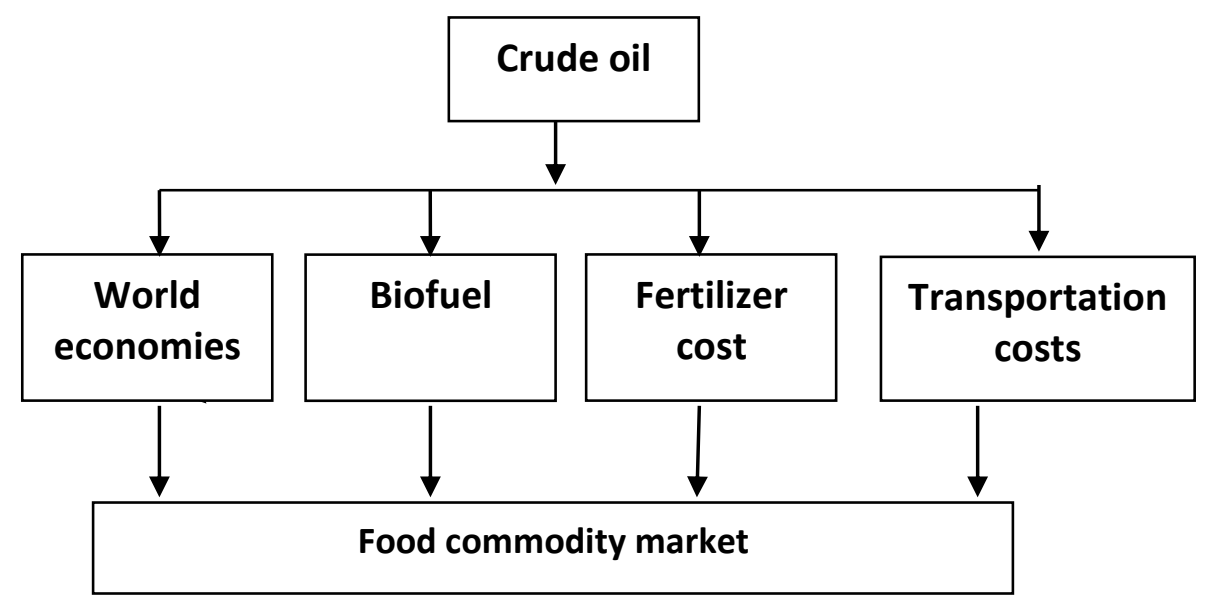

Fig. 1: Crude oil price transmission effect

The current paper adds to the existing literature by answering the following two questions. What is the impact of crude oil price fluctuations on the agricultural food commodity price changes? Does oil price volatility or its extreme price levels that matter more in the agricultural commodity price fluctuations?

The remaining parts of the paper are structured as follows: section two highlights the literature review, section three discusses the dynamics of oil price change, and section four illustrates the methodology of the research, and the final section concludes the study.

\section{Literature review}

Deaton and Laroque (1991) have investigated 95 agricultural and oil commodities price transmission mechanisms and market integration using a storage model to find out that prices are not normally distributed, as the stockholding behavior of risk-averse agents generates autoregressive pattern behavior. Such price behavior can induce the persistence of supply and demand shocks. On the supply side, this persistence is induced by correlated shocks, while on the demand side persistence is generated from working stocks that induce intertemporal correlations. However, price jumps may be instigated by speculative demand by producers' anticipation of stock-outs (Ding \& Zhang, 2020; Hau et al.2020; Fowowe 2016; Helmberger and Weaver 1982). The depreciation of the dollar value and speculations in future markets are further factors that influence agricultural commodity price movement (Robles et al., 2009, and Trostle, 2008). Also had been found that the impact of higher energy prices can be reflected in higher farm production costs causing lower growth in agricultural production and yield (Tyner and Taheripour, 2008; Trostle, 2008). The indirect effect of energy price rise includes diversion of land under crops for use of other agricultural energy-related crops (sugar, and corn), reducing their supply, and driving up their prices (Schmidhuber, 2007). The expansion in biofuels production was an important driver behind corn and oilseed demand growth (Gilbert, 2010; Zhang et al., 2010; Ciaran and d'Artis, 2011a,b). Biofuel policies, encouraging farmers to produce feed-stocks for biofuel purposes, have increased dependency between energy prices and agriculture prices (Yu et al. 2006; Campiche et al., 2007; Zhang and Reed 2008; Gilbert, 2010; 
Gohin and Chantret, 2010; Nazlioglu, 2011; Taghizadeh-Hesary et.al 2019; Pal \& Mitra, 2019; Ji et al., 2018; Al-Maadid et.al.,2017). The question that, to what extent food commodity prices are unduly volatile and unconnected to the market fundamentals has been investigated extensively by Balcombe (2009, 2013), Vo, et al. 2019; Su et al. 2019, Sarwar \& Tivari, 2020; and Gilbert (2010). The persistence of non-fundamental effects on food prices has been considered by Chatellier (2011), Listorti, and Esposti (2012), Rosa (1999). In presence of volatility overshooting above what can be accounted for by changes in market fundamentals, indicate commodity prices may reflect inefficient signals for resource allocation (Gilbert and Morgan, 2010; Balcombe and Fraser, 2013). It is important to realize that time-varying volatility of prices in general, as addressed by Engle (1982) and Myers (1992), has an effect on statistical inference as the existence of heteroscedasticity, causing loss of efficiency and biasedness of estimated standard errors (Engle, 1982). Furthermore, excess kurtosis causes additional problems as inference theory requires assumptions of normal distribution of the error terms, despite the actual distribution of prices appears to have fatter tails than the normal. This creates a problem in the maximum likelihood estimation of commodity market models (Myers, 1992).

\section{Dynamics of oil price volatility}

The trend of oil price movements went through different stages in the past decades. The first stage was a historical one, as it reflects the time when international oil prices were fully controlled by a group of major oil-producing companies, which later became the OPEC cartel. The primary aim of the OPEC group was to manage oil production in such a way that oil prices should not fall below a certain level, called reference price level. During this period, the range of oil price fluctuations was almost stable except in some short periods of political episodes in the Middle East region. In the second stage, OPEC countries lost control of becoming the exclusive price setter, but the only price determined in international markets based on a formula that combines spot and futures prices of crude oil (WTI, and Brent) as reference prices. As a result, the volatility of crude oil prices, since then, started reflecting a combination of spot and future crude prices.

Since price changes in future markets are associated with speculations of traders about future contract prices, then price changes in these markets are continuous, as they are reviewed during and between trading days depending on the inflow of information and news about crude oil production and inventories. If the news, for example, is bearish, traders reduce the price to attract more buyers and they act opposite if the news is bullish. As a result, most of the time, the short-term spot price fluctuations are mainly due to factors related to future commodity markets. When the crude oil market in contango, there is an incentive to build up stocks, as the forward price of the futures contract exceeds the spot price. But a stock build-up signals oil overproduction, and that in turn induces further fall of the spot price. Such price fall ceases only when the marginal cost of keeping more stocks becomes prohibitive. Similarly, when the crude oil market in backwardation the motive is to draw from inventories, which signal underproduction and that in turn induces price rise. As a result, in all these cases oil price 
movement is influenced only by traders' speculations about future stocks or inventories, but not by real factors related to downstream market and refiners, as it should be.

Oil prices kept rising from 2004 to historic highs in mid-2008 and then fall suddenly in the last four months of 2008 as it wiped out all the gains of the preceding four and a half years as indicated in figure 2. The steep price rise from January 2007 to July 2008 was a problem for all economies, but the sharp sudden drop of prices in August 2008 has been welcome news for consumers. A strong worldwide recession in 2008/2009 severely reduced economic activities and demand for crude oil and petroleum products, as a consequence, lowered their prices until economies began to recover. Also, supply disruptions are important factors that influence world oil markets causing significant uncertainty in energy markets and can immediately impact market prices. An example of supply disruption impacts includes when Libyan oil production dropped by over 1 million barrels per day relative to 2010 levels. Research evidence (Kilian, 2009) indicates in periods of low excess production capacity it is difficult to absorb a loss of supply without increases in prices. Following four years of relative stability at around \$108 per barrel during 2011-2014, oil prices have declined sharply by the end of 2014 and expected to stay low for a considerable time as a result of continuous increases in global liquids inventories that impose downward pressure on prices in the coming years, unless a significant supply disruption occurs.

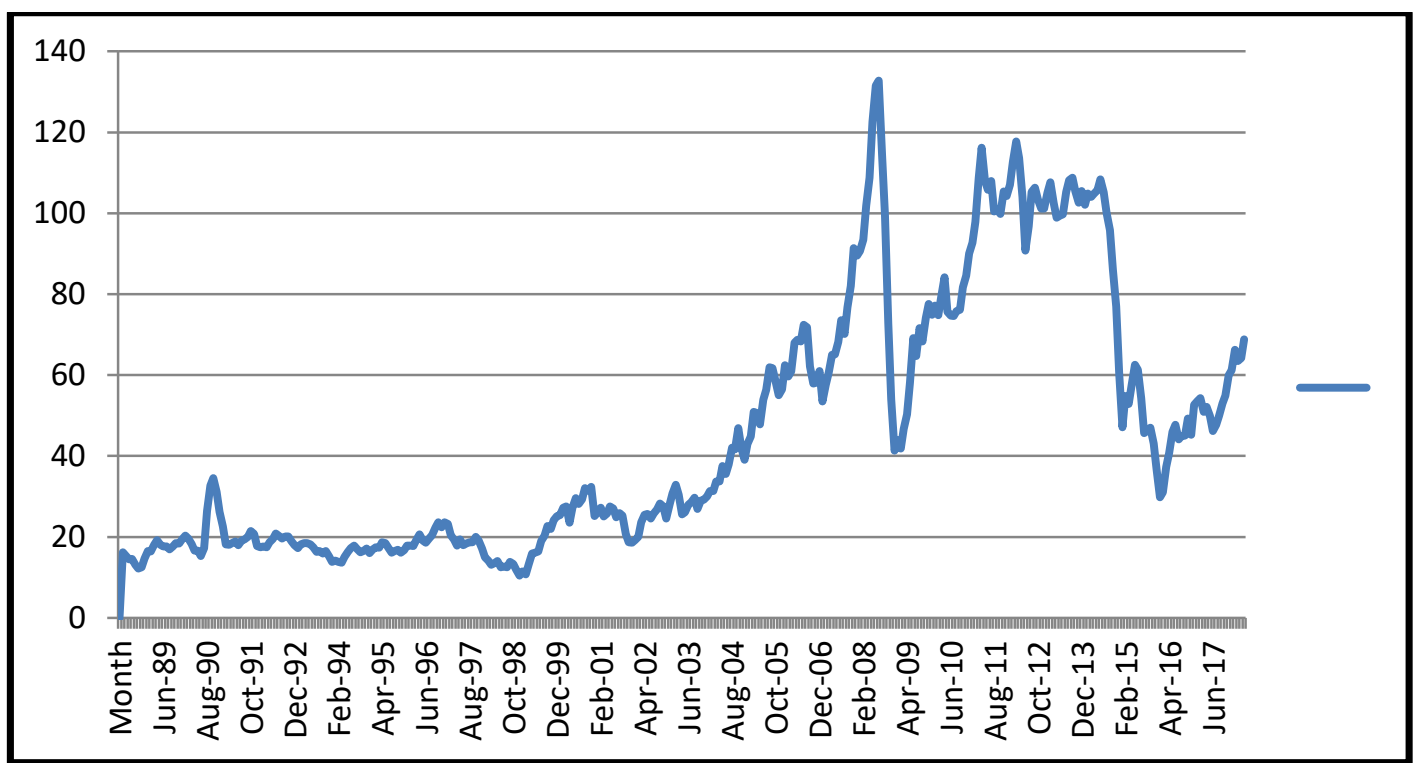

Fig. 2: Trend of crude oil price

\section{The methodology:}

To estimate the effect of crude oil price volatility transmission to major food commodity prices in this paper we employed dynamic conditional correlation (DCC) multivariate generalized autoregressive conditionally heteroskedastic (MGARCH) model. The general specification of the DCC-MGARCH model, as developed by Bollerslev et.al (1988) is:

$$
y_{t}=C X_{t}+e_{t}
$$


Where

$$
\begin{aligned}
& e_{t}=H_{t}^{1 / 2} v_{t} \\
& H_{t}=D_{t}^{1 / 2} R_{t} D_{t}^{1 / 2} \\
& R_{t}=\operatorname{diag}\left(Q_{t}^{-\frac{1}{2}}\right) Q_{t} \operatorname{diag}\left(Q_{t}^{-\frac{1}{2}}\right) \\
& Q_{t}=\left(1-\mu_{1}-\mu_{2}\right) R+\mu_{1} e_{t} e_{t-1}^{\prime}+\mu_{2} Q_{t-1}
\end{aligned}
$$

$y_{t}$ is (mx1) vector of dependent variables

$\mathrm{C}$ is (mxk) matrix of parameters

$X_{t}$ is (kx1) vector of independent variables, which may contain lags of $y_{t}$

$H_{t}^{1 / 2}$ is the Cholesky factor of the conditional covariance matrix $H_{t}$

$v_{t}$ is $(m \times 1)$ vector of independent and identically distributed innovations

$D_{t}$ is a diagonal matrix of conditional variance in which each

$\sigma_{i, t}^{2}=s_{i}+\sum_{j=1}^{p i} \alpha_{j} e_{i, t-1}^{2}+\sum_{j=1}^{q i} \beta_{j} \sigma_{i, t-j}^{2}$

$R_{t}$ is a matrix of conditional quasicorrelation.

\section{Data Analysis}

The study employs monthly price series for five commodities that include, wheat, sugar, corn, fertilizers, and crude oil prices during the sample period from January 1988 to April 2018 (360 observations $^{1}$ ). Oil price change and its volatility have long been considered a factor influencing the business cycles in commodity markets, in particular plunging the world macroeconomics into recessions when there is a sharp increase in oil prices. As a result, the oil price is frequently used as a predictor of change in food commodity prices as well as a variable of impact on transition probabilities. Plots of the price series, included in the appendices (A1 -A5), indicate there are two distinct states, for all the five commodities, a state of relatively low variability of prices, and a state of high variability. A striking feature about the price changes of the food commodities is that the high volatility period covers the time from 2006 to 2014, and the high volatility period for the oil price extend from 2004 to 2014, which is an indication that crude oil price is the common factor that influences these food commodity prices. To investigate more formally the pattern of price changes of food commodities and crude oil prices, we employed Markov switching dynamic regression to assess the transition probabilities that decompose the pattern of price changes into different states. Results of Markov switching regression support evidence of two states, which in line with the two states indicated in the graphical plots in the appendix. To distinguish the behavior of oil price fluctuations in the two states we regressed change in oil prices on time variable (the trend) and oil price levels. Regression results (table 1) reveal that state 1 corresponds to the period where oil price change follows a trend line (significance of the coefficient of the time variable), but in state 2 the trend variable is insignificant. Looking at figure 2 above, it becomes clear that state 1 refers to the period where a

${ }^{1}$ All data gathered from the Index Mundi website.

43 Published by Research E Innovation Initiative, 3112 Jarvis Ave, Warren, MI 48091, USA 
visible trend pattern can be observed for oil price changes, and that refers to the period extending from 1988 to 2005.

\section{Table 1: Markov-Switching Dynamic Regression ${ }^{2}$}

\begin{tabular}{|c|c|c|c|c|c|}
\hline Variables & coef & $\mathrm{p}$-value & variables & Coef & P-value \\
\hline$\underline{\text { State } 1}$ & & & $\underline{\text { State } 1}$ & & \\
\hline$\Delta$ wheat: & & & $\Delta$ corn: & & \\
\hline$\Delta$ oil & 0.14 & 0.40 & $\Delta$ oil & 0.52 & $0.000^{*}$ \\
\hline oil & -0.06 & $0.007^{*}$ & oil & -0.05 & $0.004^{*}$ \\
\hline Constant & 1.64 & 0.65 & onstant & 1.50 & 0.100 \\
\hline$\underline{\text { State } 2}$ & & & $\underline{\text { State } 2}$ & & \\
\hline$\Delta$ wheat: & & & $\Delta$ corn: & & \\
\hline$\Delta$ oil & 3.09 & $0.000^{*}$ & $\Delta$ oil & 0.87 & $0.000^{*}$ \\
\hline oil & 0.56 & $0.000^{*}$ & oil & 0.30 & $0.004^{*}$ \\
\hline constant & -11.3 & 0.11 & constant & -6.14 & 0.10 \\
\hline $\mathrm{LL}=-1413$ & & & $L L=-1585$ & & \\
\hline $\mathrm{AIC}=7.90$ & & & $\mathrm{AIC}=8.8$ & & \\
\hline$P 11=0.91$ & & & $P 11=0.91$ & & \\
\hline$P 21=0.80$ & & & $P 21=0.66$ & & \\
\hline$P 12=0.08$ & & & $P 12=0.09$ & & \\
\hline$P 22=0.20$ & & & $P 22=0.44$ & & \\
\hline$\underline{\text { State } 1}$ & & & $\underline{\text { State } 1}$ & & \\
\hline$\Delta$ sugar: & & & $\Delta$ oil: & & \\
\hline$\Delta$ oil & -0.07 & 0.63 & time & 0.13 & $0.000^{*}$ \\
\hline oil & -0.57 & 0.09 & oil & 0.09 & $0.009 *$ \\
\hline Constant & 9.55 & 4.97 & Constant & -57.6 & 0.000 \\
\hline$\underline{\text { State } 2}$ & & & $\underline{\text { State } 2}$ & & \\
\hline$\Delta$ sugar: & & & $\Delta$ oil & & \\
\hline$\Delta$ oil & 0.16 & 0.63 & time & -0.002 & 0.27 \\
\hline oil & 0.12 & $0.001^{*}$ & oil & 0.038 & $0.000^{*}$ \\
\hline Constant & -1.89 & 0.30 & constant & -0.40 & 0.22 \\
\hline $\mathrm{LL}=-1567$ & & & $\mathrm{LL}=-944$ & & \\
\hline $\mathrm{AIC}=8.7$ & & & $\mathrm{AIC}=5.31$ & & \\
\hline$P 11=0.45$ & & & $P 11=0.69$ & & \\
\hline$P 21=0.10$ & & & $P 21=0.02$ & & \\
\hline$P 12=0.55$ & & & $P 12=0.31$ & & \\
\hline$P 22=0.90$ & & & $P 22=0.98$ & & \\
\hline
\end{tabular}

*Significant at $1 \%$ significance level. ${ }^{* *}$ significant at $5 \%$ sig.level. Note: Pij computed using P11+P12=1, and P21+P22=1.

Markov switching results indicate in state 1, for all food commodities, the coefficients of oil price levels are significant and negatively associated with the change in food commodity prices, implying that higher levels of oil prices in this period (state 1) induce a decline in food commodity prices, and the opposite is true for lower oil price levels. However, in state 2, the coefficients of oil price levels are significant and positively associated with the change in the

\footnotetext{
${ }^{2}$ mswitch fits dynamic regression models that exhibit different dynamics across unobserved states using state-dependent parameters to accommodate structural breaks or other multiple-state phenomena. These models are known as Markovswitching models because the transitions between the unobserved states follow a Markov chain.
} 
food commodity prices, implying that higher oil price levels correspond to an increase in food commodity prices, and the opposite is holding at lower oil price levels. These results support evidence that the impact of oil prices on global food commodity prices differs depending on the size of oil price volatility. The transition probability of having state 1 an absorbing state, p11 $=0.91$, for wheat and corn commodities implies, given the prices of these two commodities are in state 1 then there is a very high probability of staying in the same state at any subsequent period. However, the transition probabilities for the same two commodities of changing from state 2 to state 1 (p21) are respectively 0.80 and 0.66 indicating that price change from one state to another still very high for the wheat compared to the corn prices. But once the prices of the two goods in state 2 , then there is a very small chance to stay in the same state for quite a long period, as indicated by the small probabilities of p22 for each of the two commodities at 0.20 and 0.44 respectively. However, the situation is quite different for the other two commodities, sugar and crude oil, which reveal state 2 is an absorbing state, as indicated by the high transition probabilities of p22 of each commodity prices at 0.90 and 0.98 respectively. Since there is a high probability of staying in state 1 , if initially in state 1 for wheat and corn commodities, and also high probabilities of staying in state 2 if initially in state 2, for the sugar and crude oil, then the important question is, what is the duration of each of these states for each commodity? Results of transition probabilities in table (1) imply that for wheat and corn commodities the duration of remaining in state 1 on average about one year (11 months), and for the sugar and crude oil the duration of remaining in state 2 is about 10 months for the sugar and 50 months for crude oil.

To estimate the impact of the oil price effect on food commodity prices, we need to employ a dynamic conditional correlation (DCC-GARCH) model. Since conditional volatility models, in general, are sensitive to unit root, we checked all price series for the Phillip-Perron unit root test reported in table (2), and show that price levels of the four commodities are non-stationary and therefore unpredictable, but their changes are stationary or predictable because they are meanreverting.

Table 2: Phillip-Perron unit root test

\begin{tabular}{|l|l|l|}
\hline Variable & Test stat* & Decision $^{* *}$ \\
\hline Level: & & \\
Wheat & 2.21 & No rejection of unit root \\
Sugar & 2.08 & No rejection of unit root \\
Crude oil & 1.79 & No rejection of unit root \\
corn & 2.74 & No rejection of unit root \\
\hline 1st difference: & & \\
Wheat & 73.06 & Rejection of unit root \\
Sugar & 67.6 & Rejection of unit root \\
Crude oil & 47.6 & Rejection of unit root \\
corn & 57.14 & Rejection of unit root \\
\hline \multicolumn{3}{|c|}{${ }^{*}$ PP test constant with a trend } \\
\hline \multicolumn{3}{|c|}{${ }^{*} 5 \%$ sig.level critical value is 4.68. } \\
\hline
\end{tabular}

Dynamic Conditional Correlation GARCH model in table (3) reveal the mean effect of oil price changes and its price level on food commodity price changes, as well as the impact of oil price level on commodities price volatility as represented by the GARCH (conditional volatility) 
effect on the four commodity prices. DCC estimation results show neither fluctuations in oil prices non-oil price levels have a statistically significant impact on change in food commodity prices. However, oil price levels influence significantly the volatility of food commodity prices. As the coefficients of oil prices are significant and positively associated with the conditional volatility of food commodity prices, implying that higher levels of oil prices, increase the volatility of food commodity prices. In other words, fluctuations in global food commodity prices are not due to impacts of oil price volatility but due to the price levels attained at extreme points.

Table 3: DCC MGARCH model: The impact of oil prices on commodity prices

\begin{tabular}{|c|c|c|c|c|c|c|c|}
\hline Variables & Coefficient & Std. err & p-value & Variables & Coefficient & Std. err & $\mathrm{p}$-value \\
\hline$\Delta$ wheat price & & & & $\Delta$ Corn price & & & \\
\hline$\Delta$ oil price & 0.34 & 0.17 & 0.04 & $\Delta$ oil price & 0.127 & 0.14 & 0.39 \\
\hline Oil price & 0.004 & 0.02 & 0.84 & Oil price & 0.009 & 0.019 & 0.62 \\
\hline Constant & -0.41 & 0.87 & 0.64 & Constant & -0.291 & 0.63 & 0.64 \\
\hline Volatility: & & & & Volatility: & & & \\
\hline $\mathrm{ARCH}:$ & & & & ARCH: & & & \\
\hline L1 & 0.27 & 0.099 & $0.005^{*}$ & L1 & 0.44 & 0.11 & $0.000^{*}$ \\
\hline $\mathrm{L} 2$ & 0.26 & 0.095 & $0.005^{*}$ & L2 & -0.23 & 0.100 & 0.022 \\
\hline GARCH: & & & & GARCH: & & & \\
\hline & 0.14 & 0.094 & 0.13 & L1 & 0.56 & 0.147 & $0.000^{*}$ \\
\hline oil price & 0.027 & 0.003 & $0.000^{*}$ & oil price & 0.031 & 0.003 & $0.000^{*}$ \\
\hline constant & 2.68 & 0.26 & $0.000^{*}$ & constant & 1.39 & 0.396 & $0.000^{*}$ \\
\hline$\Delta$ Sugar price & & & & $\Delta$ Fertilizers price & & & \\
\hline$\Delta$ oil price & 0.34 & 0.25 & 0.16 & $\Delta$ oil price & 0.49 & 0.25 & 0.057 \\
\hline Oil price & -0.04 & 0.03 & 0.28 & Oil price & 0.03 & 0.04 & 0.34 \\
\hline Constant & 0.71 & 1.15 & 0.54 & Constant & -1.49 & 1.11 & 0.18 \\
\hline Volatility: & & & & Volatility: & & & \\
\hline $\begin{array}{l}\text { ARCH: } \\
\text { L1 }\end{array}$ & 0.25 & 0.10 & 0.015 & $\begin{array}{l}\text { ARCH: } \\
\text { L1 }\end{array}$ & 0.218 & 0.10 & 0.031 \\
\hline $\mathrm{L} 2$ & -0.85 & 0.08 & 0.32 & $\mathrm{~L} 2$ & 0.116 & 0.09 & 0.24 \\
\hline GARCH: & & & & GARCH: & & & \\
\hline & 0.72 & 0.109 & $0.000^{*}$ & $\mathrm{~L} 1$ & 0.47 & 0.09 & $0.000^{*}$ \\
\hline oil price & 0.02 & 0.004 & $0.000^{*}$ & oil price & 0.04 & 0.004 & $0.000^{*}$ \\
\hline constant & 2.22 & 0.58 & $0.000^{*}$ & constant & 2.09 & 0.34 & $0.000^{*}$ \\
\hline
\end{tabular}

\section{Conclusion}

Oil price change and its volatility have long been considered a factor influencing the business cycles in commodity markets, in particular plunging the world macroeconomics into recessions when there is a sharp increase in oil prices. As a result, change in oil price is frequently used as a predictor of change in food commodity prices as well as a variable of impact on transition probabilities. Graphical plots of change in price series, included in the appendix, indicate there are two distinct states, for all the five commodities, a state of relatively low volatility of prices, and a state of higher volatility. A striking feature about the price changes of the food commodities is that the high volatility period span from 2007 to 2014, and the oil price volatility extend from 2004 to 2014, which is an indication of a common factor that influences these food 
commodity prices. To investigate more formally the pattern of price changes of food commodities, we employed Markov switching dynamic regression to assess the transition probabilities that decompose the pattern of price changes into different states. Results of Markov switching regression support evidence of two states, which is consistent with the two states indicated in the plots in the appendix. Results of Markov switching dynamic regression support evidence of two states, and indicate that in state 1, which pertain to the low volatility of crude oil price, higher levels of crude oil prices lead to a decline in food commodity prices, whereas in state 2, which refers to higher volatility of crude oil price, higher oil price levels cause an increase in food commodity prices. This evidence supports the conclusion that the impact of oil prices on global food commodity prices depends on different states of oil price volatility. The transition probabilities indicate when the prices of wheat and corn are in state 1, there is a very high probability of remaining at the same state in any subsequent period. Thus, state 1 is an absorbing state for wheat and corn, but for sugar and fertilizers, state 2 is absorbing. Regarding the duration of each of these states, our finding indicates for wheat and corn commodities the duration of remaining in state 1 on average about one year (11 months), whereas for the sugar and fertilizers the duration of remaining in state 2 respectively about 10 months and 50 months. Results of Dynamic Conditional Correlation (DCC) GARCH estimates indicate the coefficients of oil price levels are significant and positively associated with the conditional volatility of the four commodity prices, implying that fluctuations in global food commodity prices are not due to oil price volatility but due to the oil price levels attained at the extreme points.

Conflict of Interest: The author declares no conflict of interest.

\section{REFERENCES}

Al-Maadid, A.; Caporale, G.M.; Spagnolo, F.; \& Spagnolo, N. (2017). Spillovers between food and energy prices and structural breaks. International Economics, 150 (C), 1-18.

Balcombe K.(2009), The nature and determinants of volatility in agricultural prices: an empirical study from 1962 to 2008. In: Sarris, A. and Morrison, J. (eds.). The evolving structure of the world agricultural trade. Rome, Italy FAO, 09-136.

Balcombe, K., \& Fraser, I. (2013). Explosive Root Regimes and Volatility Shifts in Economic Time Series, (Draft), School of Economics University of Kent Canterbury.

Campiche, J.L., Bryant, H., L., Richardson, J. W., \& Outlaw, J. L. (2007). Examining the evolving correspondence between petroleum prices and agricultural commodity prices. The American Agricultural Economics Association Annual Meeting, Portland, OR, July 29-Aug. 1.

Chatellier V., (2011). Price volatility, market regulation, and risk management: challenges for the future of CAP. International agricultural policy, 1: 33-50.

Deaton, A. \& Laroque, G. (1995). Estimating a Non-Linear Rotational Expectations Commodity price model with Unobservable State Variables. Journal of Applied Econometrics, 10: 9-40.

Ding, S. \& Zhang, Y. (2020). Cross market predictions for commodity prices. Economic Modelling, 91:455-462.

Bollerslev, T., Engle R., \& Wooldridge J., (1988). A Capital Asset Pricing Model with Time-Varying Co-variances. Journal of Political Economy, 96,116131.

Engle, R.F. (1982). Autoregressive Conditional Heteroscedasticity with Estimates of the Variance of United Kingdom Inflation. Econometrica, 50(4): 987-1008. 
Jones, W. \& Elasri A., (2010). Rising food prices: Causes, consequences and policy responses. Cambridge University Press, Retrievable at: http://dx.doi.org/10.1017/CBO9780511712005.006

Onour, I. (2010). Global Food Crisis and Crude Oil Price Changes: Do They Share Common Cyclical Features? International Journal of Economic Policy in Emerging Economies, 3(1): 61-70.

Onour, I. \& Sergi, B.S. (2011). Modeling and Forecasting Volatility in Global Food Commodity Prices. Agricultural Economics, 57(3): 132-139.

FAO, IFAD, OECD IMF, WFP UNCTAD. (2011). Price Volatility in Food and Agricultural Markets: Policy Responses. FAO, Rome.

Fowowe, B. (2016). Do oil prices drive agricultural commodity prices? Evidence from South Africa. Energy, 104, 149-157.

Gilbert, C.L. (2010). How to understand high food prices. Journal of Agricultural Economics, 61: 398-425.

Gohin, A. \& Chantret, F. (2010). The long-run impact of energy prices on world food markets: The role of macroeconomic linkages. Energy Policy, 38(1): 333-339.

Hau, L.; Zhu, H.; Huang, R.; \& Ma, X. (2020). Heterogeneous dependence between crude oil price volatility and China's agriculture commodity futures: Evidence from quantile-on-quantile regression. Energy, 213:118781 https://doi.org/10.1016/j.energy.2020.118781

Hudson, D. (2009). The Relationship between Oil, Exchange Rates, and Commodity Prices. Journal of Agricultural and Applied Economics, 41(2): 501-510.

Helmberger, P.G., Weaver R.D., \& Haygood K.T. (1982). Rational Expectations and Competitive Pricing and Storage. American Journal of Agricultural Economics, 64: 266-270.

Ji, Q.; Bouri, E.; Roubaud, D.; \& Shahzad, S.J.H. (2018). Risk spillover between energy and agricultural commodity markets: A dependence-switching CoVaR-copula model. Energy Economics, 75 (C): 14-27.

Kilian, L. \& Park. C., (2009).The impact of oil price shocks on the U.S. stock market. Int. Econ. Rev., 50 (4): 1267-1287

Listorti, G. \& Esposti, R., (2012), Horizontal price transmission in agricultural markets: fundamental concepts and open empirical issues. Bio-base and applied economics, 1: 81-108.

Nazlioglu, S. (2011). World Oil and Agricultural Prices: Evidence from Nonlinear Causality. Energy Policy, 39: 29352943.

OECD (2008). Rising Food Prices: Causes, Consequences, and Responses. OECD Policy Brief. DOI: $10.1017 / C B O 9780511712005.006$

Robles, M., Torero M. \& von Braun, J. (2009). When speculation matters. Issue Brief 57, Washington, DC: International Food Policy Research Institute. Source: http://www. ifpri.org/sites/default/files/publications/ib57.pdf.

Rosa, F. (1999). Testing the Quality-Price Relations in Parmigiano and Padano Cheese Markets, Journal of International Food \& Agribusiness Marketing, 10(3): 19-43.

Sarwar, S.; \& Tivari, A. (2020). Analyzing volatility spillovers between oil market and Asian stock markets. Resource Policy, 66,101608. https://doi.org/10.1016/j.resourpol.2020.101608

Schmidhuber, J. (2007). Biofuels: An Emerging Threat to Europe's Food Security? Impact of an Increased Biomass Use on Agricultural Markets, Prices, and Food Security: A Longer-Term Perspective. CFE Conference Papers Series No. 2, Lund University, Sweden.

Su, C.W.; Wang, X.Q.; Tao, R.; \& Oana-Ramona, L. (2019). Do oil prices drive agricultural commodity prices? Further evidence in a global bio-energy context. Energy, 172: 691-701.

Pal, D. \& Mitra, S.K. (2019). Correlation dynamics of crude oil with agricultural commodities: A comparison between energy and food crops. Economic Modelling, 82:453-466

Taghizadeh-Hesary, F.; Rasoulinezhad, E.; \& Yoshino, N. (2019). Energy and Food Security: Linkages through Price Volatility. Energy Policy, 128: 796-806.

Trostle, R. (2008). Global Agricultural Supply and Demand: Factors Contributing to the Recent Increase in Food Commodity Prices. USDA, Economic Research Service, Report WRS-0801.

Tyner, W.E. \& Taheripour, F. (2008). Policy options for integrated energy and agricultural markets. Review of Agricultural Economics, 30: 387-396. 
Vo, D.H.; Vu, T.N.; Vo, A.T.; \& McAleer, M. (2019). Modeling the Relationship between Crude Oil and Agricultural Commodity Prices. Energies, 12, 1344

Zhang, Z., Lohr, L., Escalante, C. \& Wetzstein, M. (2010). Food versus fuel: what do prices tell us? Energy Policy, 38: $445-451$. an open-access article distributed under the terms and conditions of the Creative Commons Attribution (CC BY) license (http://creativecommons.org/licenses/by/4.0/).

\section{Appendix}
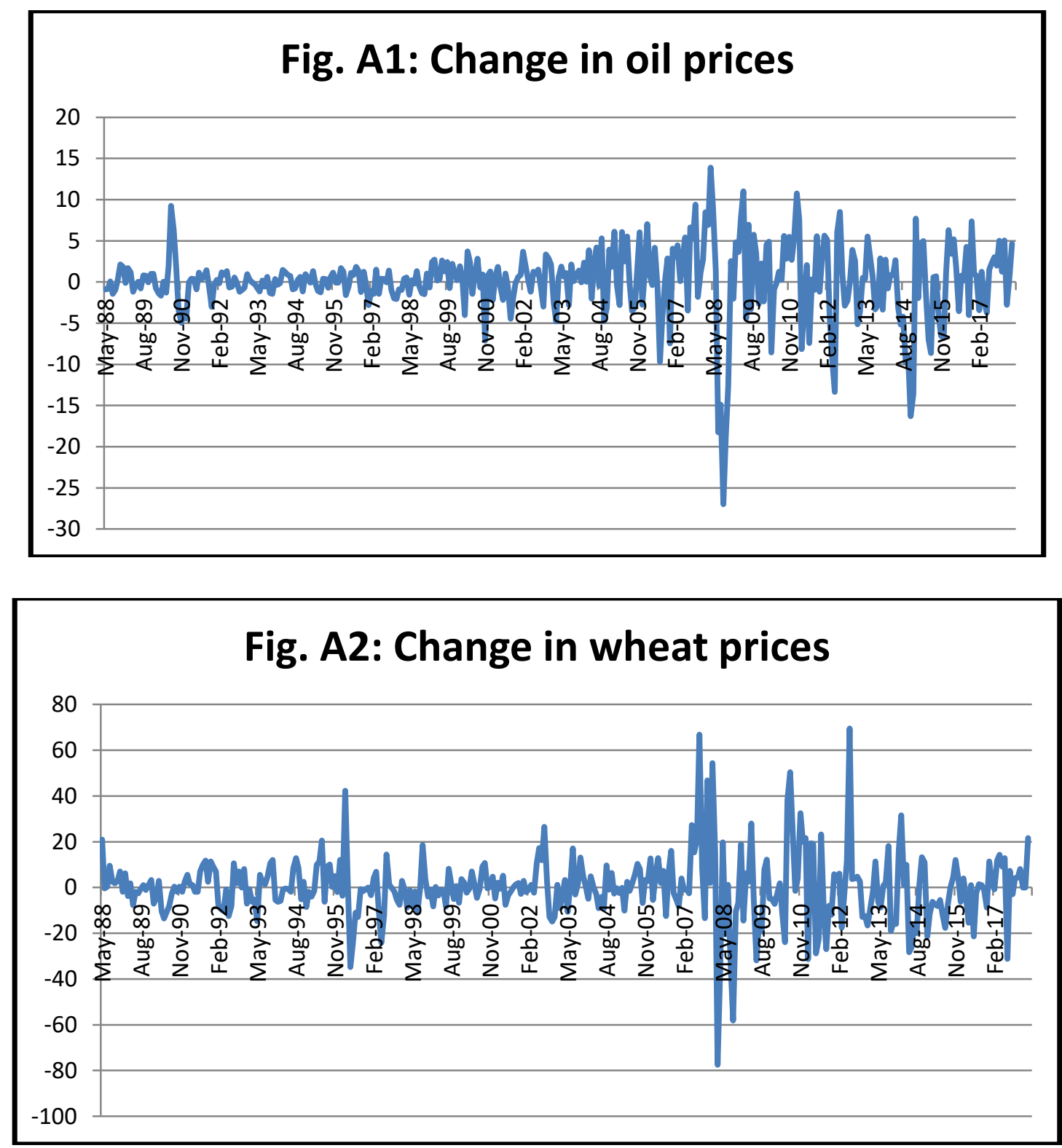


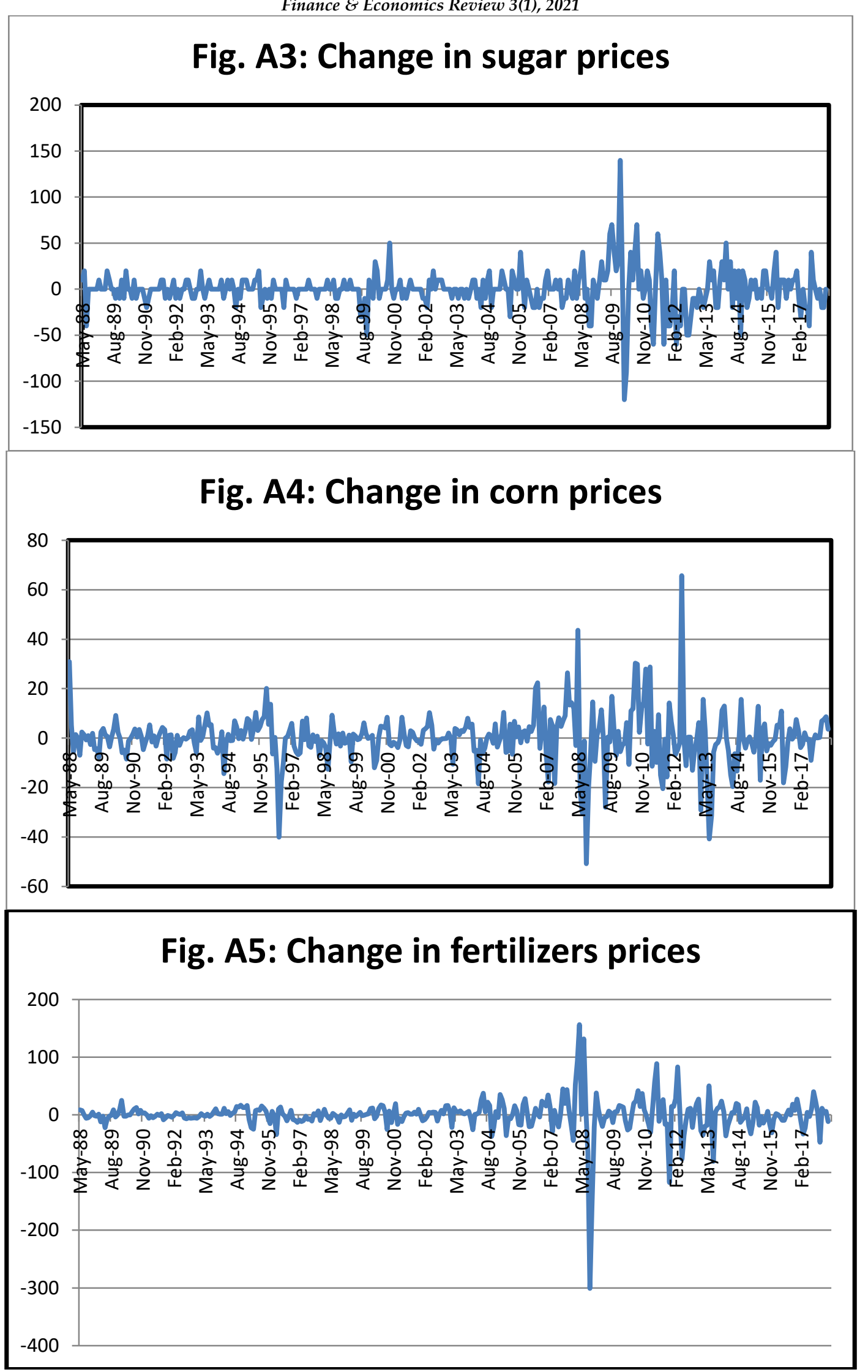

